九州大学学術情報リポジトリ

Kyushu University Institutional Repository

Backcross Compatibility in Hybrids between Brassicoraphanus (Brassica oleracea X Raphanus sativus) and Cruciferous Crops, and Clubroot Resistance in Their BC, Plants

Long, Ming Hua

Laboratory of Horticultural Science, Faculty of Agriculture, Kyushu University

Okubo, Hiroshi

Laboratory of Horticultural Science, Faculty of Agriculture, Kyushu University

Fujieda, Kunimitsu

Laboratory of Horticultural Science, Faculty of Agriculture, Kyushu University

https://doi.org/10.5109/23996

出版情報 : 九州大学大学院農学研究院紀要. 37 (1)，pp.41-50，1992-12. Kyushu University バージョン：

権利関係: 


\title{
Backcross Compatibility in Hybrids between Brassicoraphanus (Brassica oleracea X Raphanus sativus) and Cruciferous Crops, and Clubroot Resistance in Their BC, Plants
}

\author{
Ming Hua Long*, Hiroshi Okubo and Kunimitsu F'ujieda \\ Laboratory of Horticultural Science, Faculty of Agriculture, \\ Kyushu University 46-01, Fukuoka 812, Japan
}

(Received April 30, 1992)

\begin{abstract}
All the $\mathrm{F}_{1}$ hybrids between Brassicoraphanus ' $\mathrm{K}-11$ ' and cruciferous crops showed very low pollen and seed fertility. Backcrossings of the $F_{1}$ hybrids with Raphanus sativus and Brassica campestris each were successful, whereas those with $B$. oleracea were almost unsuccessful under natural conditions. $\mathrm{BC}_{1}$ plants could be obtained through embryo culture when $\mathrm{F}$, hybrids were backcrossed with $B$. oleracea. In the backcrossings with $R$. sativus and B. campestris each, seed fertility was improved as the backcross generation and selection of the plants advanced. One to three trivalents were observed in the PMCs of $\mathrm{BC}_{1}$ plants obtained by backcrossing $F_{1}$ hybrids with $B$. campestris. Clubroot resistant plants were obtained from $\mathrm{BC}$, progenies derived from backcrossing of the $\mathrm{BC}_{1}$ hybrids with $R$. sativus and $B$. campestris each.
\end{abstract}

\section{INTRODUCTION}

For breeding clubroot resistant cruciferous crops using clubroot resistant Bras. sicoraphanus 'K-11' (Fukushima, 1945; Xing et al., 1989) as a bridge plant, cross compatibility between Brassicoraphanus and susceptible cruciferous crops was investigated and their $F_{1}$ hybrids obtained were found to be strongly resistant to clubroot (Xing et al., 1989: Long et al., 1992).

To transfer clubroot resistant gene from Brassicoraphanus ' $\mathrm{K}-11$ ' to Chinese cabbage or Japanese radish, successive backcrossings are required. In the present report, backcross compatibility of the clubroot resistant $F_{1}$ hybrids and their $\mathrm{BC}$, hybrids were investigated to produce $\mathrm{BC}_{2}$ progenies. Clubroot resistance in the $\mathrm{BC}$, progenies obtained from backcrossings of the $\mathrm{BC}_{1}$ hybrids with $\mathrm{B}$. campestris and with $R$. sativus was also investigated to demonstrate the possibility of breeding clubroot resistant Chinese cabbage- and Japanese radish-like reversional plants.

\section{MATERIALS AND METHODS}

$\mathrm{F}_{1}$ hybrids obtained from the crossings between Brassicoraphanus ' $\mathrm{K}-11$ ' and selected cruciferous crops (Long et al., 1992), grown in a greenhouse, were backcrossed

\footnotetext{
* Present address : Guang Xi Agricultural University, Nan Ning, Guang Xi, China.
} 
with the cruciferous crops from early April to early May in 1988 and 1989.

$\mathrm{BC}_{1}$ plants obtained from (' $\mathrm{K}-11$ ' $\times$ B.campestris) $\mathbf{X}$ B. campestris and (' $\mathrm{K}-11$ ' $\mathbf{X}$ $\boldsymbol{R}$. sativus) $X \boldsymbol{R}$. sativus were backcrossed with $\boldsymbol{B}$. campestris and $\boldsymbol{R}$. sativus, respectively in the greenhouse from early April to early May in 1989.

Methods of backcrossing, ovary and embryo cultures and pollen tube observation were described previously (Long et al., 1992).

Stainable pollen of the $\mathrm{F}_{1}$ and $\mathrm{BC}_{1}$ plants in $1 \%$ acetocarmine was recorded as fertile. For observing meiotic configuration in BC, plants, the floral buds were fixed with acetic alcohol $(1: 3 \mathrm{v} / \mathrm{v})$ for $24 \mathrm{~h}$. After squashing the anther in a drop of $1 \%$ aceto- $^{-}$ orcein, the pollen mother cells (PMCs) were examined at metaphase-I and -11. For chromosome observation, the root tips from $\mathrm{BC}$, plants were pretreated with a solution of $0.002 \mathrm{M} 8$-hydroxyquinoline for $4 \mathrm{~h}$ at $20^{\circ} \mathrm{C}$ and fixed with acetic alcohol for more than $2 \mathrm{~h}$. Then the root tips were hydrolyzed in a mixed solution of $1 \mathrm{~N} \mathrm{HCl}$ and 45 $\%$ acetic acid $(1: 1 \mathrm{v} / \mathrm{v})$ for $90 \mathrm{sec}$ at $60^{\circ} \mathrm{C}$, stained with lacto-propionic orcein (Dyer, 1963) for more than $12 \mathrm{~h}$, and observed under a light microscope.

Table 1 . Pollen fertility in $F_{1}$ hybrids between Brassicoraphanus and cruciferous crops.

\begin{tabular}{|c|c|c|c|}
\hline $\begin{array}{l}\text { Cross } \\
\text { combination }\end{array}$ & $\begin{array}{l}\text { No. of } \\
\text { pollen } \\
\text { grains } \\
\text { examined }\end{array}$ & $\begin{array}{l}\text { No. of } \\
\text { fertile } \\
\text { pollen } \\
\text { grains }\end{array}$ & $\begin{array}{l}\text { Pollen } \\
\text { fertility } \\
(\%)\end{array}$ \\
\hline \multicolumn{4}{|c|}{ Brassicoraphanus $\mathbf{X}$ Brassica campestris } \\
\hline K-11 X Hiroshimana & 519 & 18 & 3.47 \\
\hline $\mathrm{K}-11 \times$ Santo & 463 & 22 & 4.75 \\
\hline K-11 × Kyoto No.3 & 373 & 84 & 22.52 \\
\hline K-11 X Nagasakiaka & 630 & 18 & 2.86 \\
\hline K-11 X Hakatasuwari & 402 & 7 & 1.74 \\
\hline Total or mean & 2387 & 149 & 6.24 \\
\hline \multicolumn{4}{|c|}{ Brassicoraphanus $\times$ B. oleracea } \\
\hline K-11 X Miikechusei & 371 & 5 & 1.35 \\
\hline K-11 X Hakushin & 693 & 7 & 1.01 \\
\hline $\mathrm{K}-11 \quad \mathrm{X}$ kale $(\mathrm{W})^{2}$ & 652 & 85 & 13.04 \\
\hline $\mathrm{K}-11 \mathrm{X}$ kale $(\mathrm{Y})^{\mathrm{y}}$ & 917 & 12 & 1.31 \\
\hline Total or mean & 2633 & 109 & 4.14 \\
\hline \multicolumn{4}{|c|}{ Brassicoraphanus $\mathbf{X}$ Raphanus sativus } \\
\hline K-11 X Minowase & 569 & 87 & 15.29 \\
\hline \multicolumn{4}{|c|}{ Brassicoraphanus $\times$ amphidiploid } \\
\hline K-11 X Shore? & 854 & 597 & 69.91 \\
\hline $\mathrm{K}-11 \times \mathrm{JS} "$ & 1067 & 560 & 52.48 \\
\hline Total or mean & 1921 & 1157 & 60.23 \\
\hline
\end{tabular}

"kale with white flowers.

${ }^{\mathrm{y}} \mathrm{kale}$ with yellow flowers.

${ }^{\mathrm{x}} B . \mathbf{X}$ napus (B. oleracea X B. campestirs).

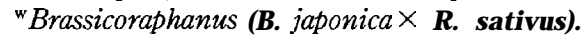


Clubroot resistance in $\mathrm{BC}_{2}$ progenies of Brassicoraphanus ' $\mathrm{K}-11$ ' backcrossed with Chinese cabbage or Japanese radish was compared with that in their pollen parents. Pathogens were Williams' races 2 and 4. Culture and inoculation methods of the pathogens and evaluation of clubroot resistance were described previously (Xing et al., 1989). The spore load was $4.1 \times 10^{5}$ per gram of dry matter. The seeds were sown on

Table 2. Backcross compatibility in $\mathrm{F}_{1}$ hybrids between Brassicoraphanus 'K-11' and cruciferous crops.

$\begin{array}{lllllll}\begin{array}{l}\text { Pollen } \\ \text { parent and }\end{array} & \text { P.G.I." } & \begin{array}{l}\text { No. of } \\ \text { flowers } \\ \text { backcross } \\ \text { combination }\end{array} & \begin{array}{l}\text { No. of } \\ \text { siliques } \\ \text { pollinated }\end{array} & \begin{array}{l}\% \text { of } \\ \text { silique } \\ \text { set }\end{array} & \begin{array}{l}\text { No. of } \\ \text { seeds } \\ \text { obtained } \\ \text { (B) }\end{array} & \\ & & \text { (A) } & & \text { B/A }\end{array}$

\begin{tabular}{|c|c|c|c|c|c|c|}
\hline \multicolumn{7}{|l|}{ B. campestris } \\
\hline (K-11 xHiroshimana) xHiroshimana & 4.0 & 667 & 574 & 86 & 5 & 0.009 \\
\hline (K-11 x Santo) X Kyoto No.3 & 4.0 & 501 & 451 & 90 & 9 & 0.020 \\
\hline$(\mathrm{K}-11$ x Kyoto No.3) x Kyoto No.3 & 4.0 & 1020 & 377 & 37 & 16 & 0.042 \\
\hline (K-11 xNagasakiaka) xNagasakiaka & 3.5 & 174 & 96 & 55 & 11 & 0.115 \\
\hline (K-11 xHakatasuwari) x Hakatasuwari & 4.0 & 584 & 485 & 83 & 6 & 0.012 \\
\hline Total or mean & 3.9 & 2946 & 1953 & 66 & 47 & 0.024 \\
\hline \multicolumn{7}{|l|}{ B. oleracea } \\
\hline (K-11 x Miikechusei) x Miikechusei & 3.9 & 948 & 910 & 96 & 2 & 0.002 \\
\hline (K-11 x Miikechusei) $\times$ Hakushin & 3.8 & 645 & 613 & 95 & 3 & 0.005 \\
\hline (K-11 X Miikechusei) $\times$ kale $(W)$ & 3.7 & 666 & 626 & 94 & 5 & 0.008 \\
\hline (K-11 x Miikechusei) X kale(Y) & 3.6 & 760 & 714 & 94 & 0 & 0 \\
\hline (K-11 xHakushin) xHakushin & 4.0 & 518 & 357 & 69 & 9 & 0.025 \\
\hline (K-11 xHakushin) $\times$ Miikechusei & 4.0 & 316 & 196 & 62 & 6 & 0.030 \\
\hline$(\mathrm{K}-11 \times \operatorname{kale}(\mathrm{W})) \times \operatorname{kale}(\mathrm{W})$ & 3.8 & 475 & 290 & 61 & 0 & 0 \\
\hline (K-11 xkale(W)) X Miikechusei & 4.0 & 327 & 252 & 77 & 0 & 0 \\
\hline$(\mathrm{K}-11 \times \operatorname{kale}(\mathrm{Y}) \times \operatorname{kale}(\mathrm{Y})$ & 3.6 & 594 & 77 & 13 & 1 & 0.013 \\
\hline Total or mean & 3.8 & 5249 & 4035 & 77 & 26 & 0.006 \\
\hline \multicolumn{7}{|l|}{ R. sativus } \\
\hline$(\mathrm{K}-11 \times$ Minowase $) \times$ Minowase & 4.0 & 367 & 187 & 51 & 167 & 0.893 \\
\hline \multicolumn{7}{|l|}{ Amphidiploid } \\
\hline (K-11 X Shoren) $\times$ Shoren & 4.0 & 76 & 42 & 55 & 52 & 1.238 \\
\hline$(\mathrm{K}-11 \times \mathrm{JS}) \times \mathrm{JS}$ & 3.8 & 289 & 211 & 73 & 130 & 0.616 \\
\hline (K-11 $\times$ Shoren) open pollinated & - & & & & - & 1.580 \\
\hline$(\mathrm{K}-11 \times \mathrm{JS})$ open pollinated & - & - & & & & 0.190 \\
\hline
\end{tabular}

"pollen germination index $=(b+2 c+3 d+4 e) /(a+b+c+d+e)(0 \leqq$ P.G.I. $\leqq 4)$. No. of pistils without pollen grains on the stigma (a), with pollen grains not germinated (b), with pollen grains germinated (c), with pollen tubes reaching to the style (d) and with pollen tubes penetrating into the ovule (e).

Table 3. Degeneration of ovule in $F_{1}$ hybrid ('K-11' $\times$ 'Hakushin') pollinated with 'Hakushin'.

\begin{tabular}{ccccccc}
\hline \multirow{2}{*}{ Cross combination } & \multicolumn{6}{c}{$\begin{array}{c}\text { No. of viable ovules per silique in } \\
\text { indicated }\end{array}$} \\
\cline { 2 - 7 } & 7 & 11 & 15 & 20 & 25 & 27 \\
\hline K-11 x Hakushin & 20.1 & 2.8 & 0.4 & 0.3 & 0.1 & 0 \\
\hline
\end{tabular}


Table 4. Results of in vitro culture of the embryos taken from the $F_{1}$ plants 27 days after pollination with $B$. oleracea.

\begin{tabular}{|c|c|c|c|c|c|c|c|}
\hline \multirow[t]{2}{*}{ Backcross combination } & \multirow[t]{2}{*}{$\begin{array}{l}\text { No. of } \\
\text { embryos } \\
\text { cultured }\end{array}$} & \multicolumn{4}{|c|}{$\begin{array}{l}\text { No. of embryos with } \\
\text { indicated stage of } \\
\text { embryo development" } \\
\text { at the initiation of } \\
\text { culture }\end{array}$} & \multirow[t]{2}{*}{$\begin{array}{l}\text { Length } \\
\text { of embyos } \\
\text { cultured } \\
(\mathrm{mm})\end{array}$} & \multirow[t]{2}{*}{$\begin{array}{l}\text { No. of } \\
\text { plantlets } \\
\text { obtained }\end{array}$} \\
\hline & & G & $\mathrm{H}$ & $\mathrm{T}$ & NM & & \\
\hline (K-11 x Miikechusei) $x$ Hakushin & 2 & 0 & 0 & 2 & 0 & 1.15 & 0 \\
\hline (K-11 x Hakushin) X Miikechusei & 5 & 0 & 0 & 1 & 4 & 1.32 & 4 \\
\hline (K-11 x Hakushin) $x$ Hakushin & 10 & 0 & 1 & 4 & 5 & 1.05 & 5 \\
\hline (K-11 X kale(W)) X kale(W) & 1 & 0 & 0 & 0 & 1 & 1.70 & 1 \\
\hline
\end{tabular}

${ }^{\mathrm{z}} \mathrm{G}$; globular stage, $\mathrm{H}$; heart stage, $\mathrm{T}$; torpedo stage, NM; nearly mature stage.

July 6, 1989 and the degree of clubbing in the roots was examined on August 18, 1989.

\section{RESULTS}

\section{Backcross compatibility in $F_{1}$ hybrids}

The $F_{1}$ plants grew slowly and resembled the maternal parents in their morphology until they had four to six leaves. Then they rapidly grew into large and vigorous plants of which the morphology was almost intermediate between their parental species. Flowers of all the hybrids were white as Brassicoraphanus bears.

Pollen fertilities of the $\mathrm{F}_{1}$ hybrids of ' $\mathrm{K}-11^{\prime} \times \mathbf{B}$. campestris, $\mathrm{X}$ B. oleracea and $\mathrm{X}$ $R$. sativus were low (Table 1). Rates of densely stained pollen were only one to $23 \%$ in these $F_{1}$ hybrids, while those in the $F_{1}$ hybrids between ' $\mathrm{K}-11$ ' and amphidiploids 'Shoren' and 'JS' were more than $50 \%$.

Although all the backcrossed $F_{1}$ plants showed high pollen germination index ( $\mathrm{P}$. G.I.) value, percentage of the siliques set and number of seeds per silique varied depending on the combinations (Table 2). Seed setting was zero or very low in the backcrossings with B. oleracea and with B. campestris in spite of considerable rate of silique set, while those with $R$. sativus and with the amphidiploids resulted in high backcross compatibilities. Among them, the backcrossing with 'Shoren' produced the greatest number of seeds per silique. The $\mathrm{F}_{1}$ hybrids from ' $\mathrm{K}-11$ ' $\times$ 'Shoren' and from 'K-11' X 'JS' produced 1.6 and 0.2 seeds per silique by open pollination, respectively. In the backcrossing with 'Hakushin' (B. oleracea), number of survived ovules decreased rapidly and no viable ovule was observed 27 days after pollination (DAP) (Table 3).

Most of the hybrid embryos in the backcrossings with B. oleracea developed in vivo beyond a torpedo or a nearly mature stage' and the lengths of them were approximately $1.2 \mathrm{~mm}$ (Table 4). Some of them grew into plantlets after culturing on White's medium supplemented with $300 \mathrm{mgl}^{-1}$ casamino acid and $30 \mathrm{gl}^{-1}$ sucrose.

Seeds were obtained in vitro from the ovaries only from ('K-11' $\mathrm{X}$ 'Hakushin') $\mathrm{X}$ 'Hakushin' among those from ('K-11' X B. oleracea) $\times$ B. oleracea 4 or 8 DAP (Table $5)$. 


\section{Backcross compatibility in $\mathbf{B C}_{1}$ hybrids}

Four types of chromosome number $(2 \mathrm{n}=38,27,26,24)$ were observed in $\mathrm{BC}_{1}$ plants from ('K-11' X B.campestris) XB.campestris (Table 6). Pollen stainability was high in the $\mathrm{BC}$, plants with 38 chromosome number, but low in those with 27 chromosome

Table 5. Results of ovary culture of $\mathrm{F}_{1}$ hybrids (Brassicoraphanus X B. oleracea) pollinated with B. Oleracea.

\begin{tabular}{|c|c|c|c|c|c|}
\hline $\begin{array}{l}\text { Backcross } \\
\text { combination }\end{array}$ & $\begin{array}{l}\text { Days } \\
\text { after } \\
\text { polli- } \\
\text { nation }\end{array}$ & $\begin{array}{l}\text { Intial } \\
\text { ovary } \\
\text { length } \\
(\mathrm{mm}) \text {, }\end{array}$ & Medium" & $\begin{array}{l}\text { No. of } \\
\text { ovaries } \\
\text { cultured }\end{array}$ & $\begin{array}{l}\text { No. of } \\
\text { seeds } \\
\text { obtained }\end{array}$ \\
\hline$(\mathrm{K}-11 \times$ Miikechusei $) \times$ Miikechusei & 8 & $20.0 f 2.1$ & A & 30 & 0 \\
\hline$(\mathrm{K}-11 \times$ Miikechusei) $\mathrm{X}$ kale $(\mathrm{Y})$ & 8 & $20.8 \mathrm{f} 1.4$ & $\mathrm{~A}$ & 30 & 0 \\
\hline (K-11 X Miikechusei) X kale(W) & 8 & $21.6 \pm 2.1$ & $\mathrm{~A}$ & 30 & 0 \\
\hline (K-11 X Miikechusei) X Hakushin & 8 & $27.6 \pm 1.9$ & $\mathrm{~A}$ & 30 & 0 \\
\hline \multirow[t]{2}{*}{ (K-11 X Hakushin) X Hakushin } & 4 & $15.2 \mathrm{f} 1.9$ & $\mathrm{~B}$ & 94 & 6 \\
\hline & 4 & & $\mathrm{C}$ & 50 & 2 \\
\hline (K-11 X Hakushin) X Miikechusei & 4 & $16.2 \mathrm{f} 1.7$ & B & 50 & 0 \\
\hline \multirow[t]{2}{*}{ (K-11 X kale(W)) X kale(W) } & 4 & $15.7 \mathrm{f} 1.6$ & $\mathrm{~B}$ & 50 & 0 \\
\hline & 4 & & $\mathrm{C}$ & 50 & 0 \\
\hline \multirow[t]{2}{*}{$(\mathrm{K}-11 \mathrm{X}$ kale $(\mathrm{W})) \mathrm{X}$ Miikechusei } & 4 & $19.7 \pm 1.5$ & $\mathrm{~B}$ & 50 & 0 \\
\hline & 4 & $12.7 \pm 0.8$ & $\mathrm{~B}$ & 50 & 0 \\
\hline$(\mathrm{K}-11 \mathrm{X}$ kale $(\mathrm{Y})) \mathrm{X}$ kale(Y) & 4 & & $\mathrm{C}$ & 50 & 0 \\
\hline
\end{tabular}

${ }^{2}$ mean \pm S.D.

${ }^{\mathrm{y}} \mathrm{A}$; Murashige and Skoog medium (1962), B; White medium (1963) + $500 \mathrm{mgl}^{-1}$ casein hydrolysate, C; White medium $(1963)+300 \mathrm{mgl}^{-1}$ casamino acid.

Table 6. Chromosome number and pollen fertility in $\mathrm{BC}_{1}$ hybrids derived from Brassicoraphanus $\times$ cruciferous crops.

\begin{tabular}{|c|c|c|c|c|}
\hline $\begin{array}{l}\text { BC, hybrid with indicated } \\
\text { backcross combination }\end{array}$ & $2 n$ & $\begin{array}{l}\text { No. of } \\
\text { pollen } \\
\text { grains } \\
\text { examined }\end{array}$ & $\begin{array}{l}\text { No. of } \\
\text { fertile } \\
\text { pollen } \\
\text { grains }\end{array}$ & $\begin{array}{l}\text { Pollen } \\
\text { fertility } \\
(\%)\end{array}$ \\
\hline \multicolumn{5}{|l|}{ (Brassicoraphanus X B. campestris) $\times$ B. campestris } \\
\hline $\mathrm{KS}-\mathrm{K}-1^{\mathrm{z}}$ & 24 & 534 & 63 & 11.8 \\
\hline KS-K-Z & 38 & 1023 & 695 & 67.9 \\
\hline $\mathrm{KS}-\mathrm{K}-3$ & 27 & 823 & 10 & 1.2 \\
\hline $\mathrm{KS}-\mathrm{K}-4$ & 24 & 968 & 22 & 2.3 \\
\hline $\mathrm{KS}-\mathrm{K}-1$ & 27 & 643 & 224 & 34.8 \\
\hline $\mathrm{KS}-\mathrm{K}-2$ & 26 & 421 & 1 & 0.2 \\
\hline $\mathrm{KS}-\mathrm{K}-3$ & 38 & 615 & 520 & 84.6 \\
\hline $\mathrm{KS}-\mathrm{K}-4$ & 27 & 869 & 1 & 0.1 \\
\hline $\mathrm{KS}-\mathrm{K}-5$ & 38 & 885 & 727 & 82.1 \\
\hline $\mathrm{KS}-\mathrm{K}-1$ & 24 & 1016 & 38 & 3.7 \\
\hline KS-K-1 & 24 & 844 & 568 & 67.3 \\
\hline \multicolumn{5}{|l|}{ (Brassicoraphanus $X$ R. sativus) $X$ R. sativus } \\
\hline 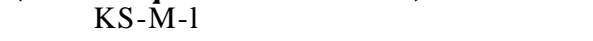 & 19 & 910 & 328 & 36.0 \\
\hline
\end{tabular}


number except 'KK-K-I', in those with 24 chromosome number except 'KH-H-I', and in 'KK-K-2' with 26 chromosome number. 'KK-K-I' and 'KH-H-I' showed moderate pollen stainability. Pollen stainability in 'KM-M-I' derived from ('K-11' $x \mathrm{R}$. sativus) $X$ R. sativus was also moderate.

All the backcrossed plants showed high P.G.I. values, but the seed set was lower in the $\mathrm{BC}$, plants derived from ('K-11' $\times$ B.campestris $) \times \mathbf{B}$. campestris than in those from ('K-11' $X$ R. sativus) $\times \mathbf{R}$. sativus irrespective of their chromosome number and pollen stainability (Table 7). Only 'KS-K-I' showed a little high seed fertility, while 'KN-N-I' X 'Nagasakiaka', 'KK-K-I' X 'Kyoto No.3' and 'KK-K-4' x 'Kyoto No. 3 ' gave very low silique and seed settings.

Although the $2 \mathrm{n}$ chromosome numbers were both 24 in 'KS-K-I' and 'KS-K-4', the chromosome pairings at metaphase-I were different between them (Table 8). Frequency of trivalent chromosome was higher in 'KS-K-I' than in 'KS-K-4'. The chromosome distributions at metaphase-II were almost the same in the two hybrids, and both of them showed a relatively high frequency of lagging chromosome (Table 9).

\section{Clubroot resistance in $\mathrm{BC}_{2}$ progenies}

Clubroot resistance was none or low in Chinese cabbage, while it was high in Japanese radish and Brassicoraphanus (Table 10). The $\mathrm{BC}_{2}$ progenies from 'KM-M1 ' $\times$ 'Minowase' resembled 'Minowase' in their morphology, and showed almost the same degree of strong resistance to two races of P.brassicae as 'Minowase' showed, although the percentage of infected plants was lower in the $\mathrm{BC}_{2}$ progenies than in 'Minowase'. More than a half of the BC, progenies from 'KS-K-I' X 'Kyoto No.3' were severely infected, but the remainings were slightly or not. Chromosome numbers were 23 in two, 24 in two and 25 in three plants of the $\mathrm{BC}_{2}$ progenies derived from 'KSK-l' x 'Minowase'.

\section{DISCUSSION}

\section{Backcross compatibility in $\mathbf{F}_{1}$ hybrids}

Low fertility in the $F_{1}$ hybrids is in agreement with the previous reports (Honma and Heeckt, 1962; McNaughton, 1973; McCollum, 1979). The loss of seed fertility in the backcrosses also agrees with the findings that successive backcrosses of Raphanobrassica with B. oleracea are unsuccessful because of low seed fertility in successively backcrossed generations and complete seed sterility in $\mathrm{BC}_{6}$ hybrids (McCollum, 1979).

Although the seed fertility of 'K-11' $\mathrm{X}$ amphidiploids, 'Shoren' and 'JS', was very low as compared with that of ' $\mathrm{K}-11$ ' $\times$ diploid cruciferous crops (Long et al., 1992), the $\mathrm{F}_{1}$ hybrids backcrossed with 'Shoren' and 'JS' showed high seed fertility, and they also produced many seeds by open pollination. The reasons for high seed fertility in our results are not clear, but one possibility is that autosyndesis in the $F_{1}$ hybrids being allotetraploid may play an important role.

\section{R escuing $\mathrm{BC}_{1}$ plants through embryo and ovary cultures}

The incompatibility occurred in the backcrossings of $\mathrm{F}_{1}\left({ }^{\prime} \mathrm{K}-11\right.$ ' $\times$ B. oleracea) with B.oleracea was able to be overcome by the culture of embryos which were beyond a torpedo stage. It is, however, extremely difficult to obtain them, and the hybrid seeds 
Table '7. Backcross compatibility in $\mathbf{B C}_{1}$ hybrids derived from (Brassicoraphanus $\mathbf{X} \mathbf{B}$. campestris) $\mathbf{X}$ B. campestris and (Brassicoraphanus $\mathbf{x}$ R. sativus) $\mathbf{x}$ R. sativus.

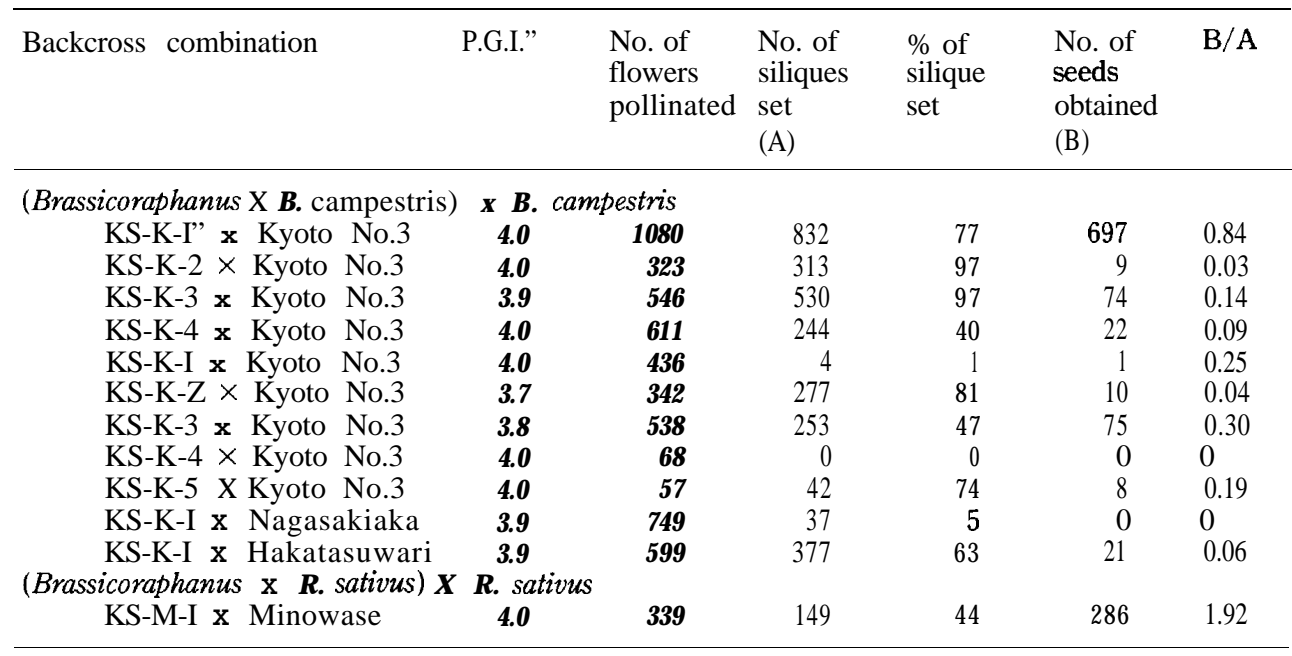

${ }^{z}$ pollen germination index $=(b+2 c+3 d+4 e) /(a+b+c+d+e)(0 \leqq P . G . I . \leqq 4)$. No. of pistils without pollen grains on the stigma (a), with pollen grains not germinated (b), with pollen grains germinated (c), with pollen tubes reaching to the style (d) and with pollen tubes penetrating into the ovule (e). ${ }^{y} \mathrm{KS}-\mathrm{K}$; ( 'K-11' x 'Santo') x 'Kyoto No.3', 'KK-K'; ('K-11' x 'Kyoto No.3') x 'Kyoto No.3', 'KN N'; ('K-11' x 'Nagasakiaka') x 'Nagasakiaka', 'KH-H'; ('K-11' x 'Kyoto No.3') × 'Kyoto No.3', 'KN N'; ('K-11' x 'Minowase') x 'Minowase'.

Table 8. Chromosome associations at metaphase-I in hybrids derived from (Brassicoraphanus X B. campestris) X B. campestris.

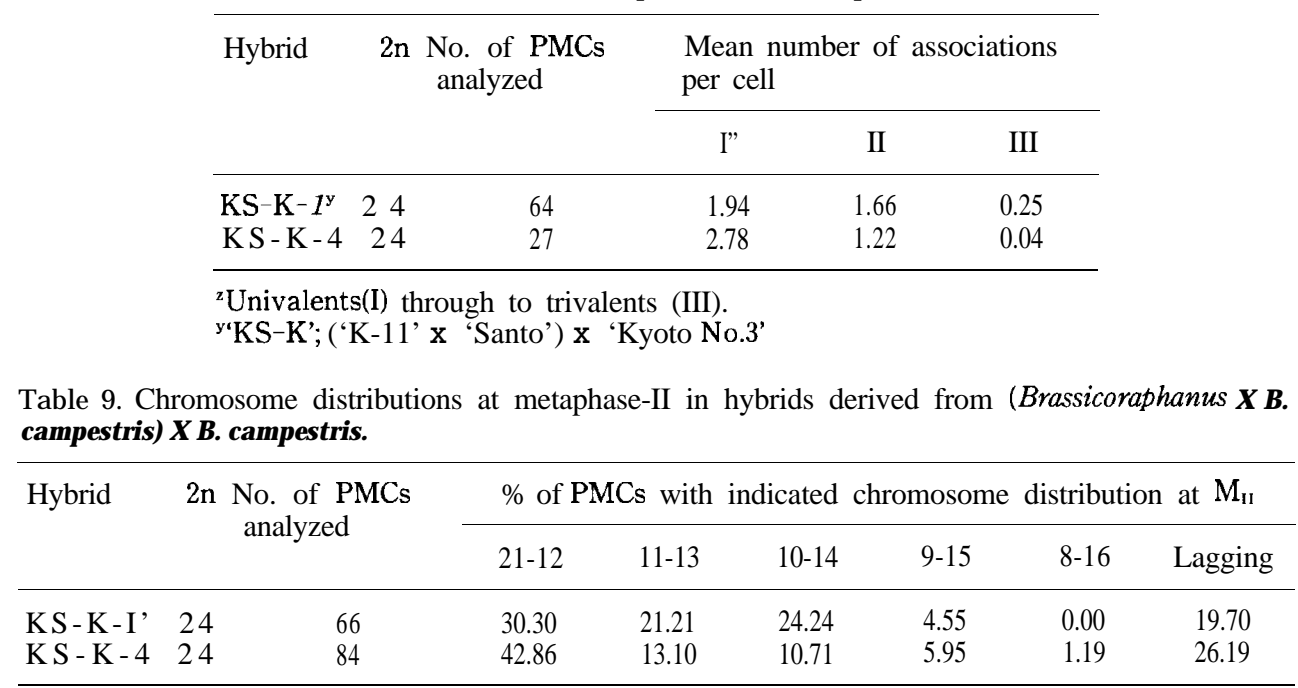

Table 9. Chromosome distributions at metaphase-II in hybrids derived from (Brassicoraphanus $\mathbf{X}$ B. campestris) X B. campestris.

“'KS-K'; ('K-11' x 'Santo') x 'Kyoto No.3'. 
Table 10. Response of Brassicoraphanus, cruciferous crops and their $\mathrm{BC}_{2}$ hybrids to clubroot disease.

\begin{tabular}{|c|c|c|c|c|c|c|c|c|c|}
\hline \multirow{2}{*}{$\begin{array}{l}\text { Strain, } \\
\text { cultivar } \\
\text { and hybrid }\end{array}$} & \multirow[t]{2}{*}{$\operatorname{Race}^{z}$} & \multirow{2}{*}{$\begin{array}{l}\text { No. of } \\
\text { plants } \\
\text { examined }\end{array}$} & \multicolumn{6}{|c|}{$\begin{array}{l}\text { No.of infectedplantsin \% of } \\
5 \text { classes of infection }{ }^{y} \text { infected }\end{array}$} & \multirow[t]{2}{*}{$\begin{array}{l}\text { Disease } \\
\text { index }^{x}\end{array}$} \\
\hline & & & A & B & $\mathrm{C}$ & $\mathrm{D}$ & $\mathrm{E}$ & Ilts & \\
\hline \multicolumn{10}{|l|}{ Chinese cabbage } \\
\hline \multirow[t]{2}{*}{ Nozaki No.2 } & 2 & 15 & 0 & 0 & 0 & & 14 & 100 & 97 \\
\hline & 4 & 15 & 0 & 0 & 0 & 0 & 15 & 100 & 100 \\
\hline \multirow[t]{2}{*}{ Kyoto No.3 } & 2 & 15 & 0 & 0 & 0 & 0 & 15 & 100 & 100 \\
\hline & 4 & 15 & 0 & 0 & 0 & 0 & 15 & 100 & 100 \\
\hline \multicolumn{10}{|l|}{ Japanese radish } \\
\hline \multirow[t]{2}{*}{ Minowase } & 2 & 15 & 13 & 2 & 0 & 0 & 0 & 13 & 1 \\
\hline & 4 & 15 & 3 & 12 & 0 & 0 & 0 & 80 & 8 \\
\hline \multirow{2}{*}{ Shijunichi } & 2 & 15 & 15 & 0 & 0 & 0 & 0 & 0 & 0 \\
\hline & 4 & 15 & 15 & 0 & 0 & 0 & 0 & 0 & 0 \\
\hline \multicolumn{10}{|l|}{ Brassicoraphanus } \\
\hline \multirow[t]{2}{*}{$\mathrm{K}-11$} & 2 & 15 & 15 & 0 & 0 & 0 & 0 & 0 & 0 \\
\hline & 4 & 15 & 15 & 0 & 0 & 0 & 0 & 0 & 0 \\
\hline \multicolumn{10}{|l|}{ BC, hybrids" } \\
\hline \multirow[t]{2}{*}{ KS-K-1 x Kyoto No.3 } & 2 & 13 & 5 & 2 & 0 & 3 & 3 & 62 & 38 \\
\hline & 4 & 7 & 2 & 0 & 1 & 0 & 4 & 71 & 61 \\
\hline \multirow[t]{2}{*}{ KS-K-I X Minowase } & 2 & 15 & 14 & 1 & 0 & 0 & 0 & 7 & 1 \\
\hline & 4 & 15 & 10 & 5 & 0 & 0 & 0 & 33 & 3 \\
\hline
\end{tabular}

"2 and 4; Williams' races 2 and 4, respectively.

'Degree of clubbing in roots. A; nonclubbed, B; slightly clubbed, C; moderately clubbed, D; severely clubbed, E; very severely clubbed.

${ }^{x}$ Disease index $=(0 \mathrm{~A}+10 \mathrm{~B}+30 \mathrm{C}+40 \mathrm{D}+50 \mathrm{E}) /(\mathrm{A}+\mathrm{B}+\mathrm{C}+\mathrm{D}+\mathrm{E})$, where $\mathrm{A}$ to $\mathrm{E}$ are the number of infected plants in each degree of clubbing.

“'KS-K'; ('K-11' x 'Santo') x 'Kyoto No.3', 'KM-M'; ('K-11' × 'Minowase') $\times$ 'Minowase'.

are hardly obtainable through ovary culture. It seems that the degeneration of ovules, endosperm and embryos in the backcrossings occurs earlier than in the initial crossings. Further effective embryo and ovary culture techniques including assertion of appropriate embryonal stage for culture and improvement of culture medium to rescue very immature embryos will be required for improving the hybrid plant production.

\section{Backcross compatibility in $\mathrm{BC}$, plants}

Our results that there was no relation between pollen fertility in $\mathbf{B C}_{1}$ plants derived from ('K-11' $\times$ B. campestris) $\mathbf{X}$ B. campestris are in agreement with Iwasa's (1964) report. It is noticeable that the seed fertility increases as the backcross generation and its selection advance, and that the backcrosses of $\mathrm{BC}_{1}$ plants $\times \boldsymbol{B}$. campestris and $\times$ R. sativus are more successful than the initial backcrosses under natural conditions. Generally, it is thought that seed sterility in hybrids is a manifestation of incongruity between different genetic backgrounds of parental species. Hybrids are the complex of various unbalanced combinations of different genes. If the unbalance is recovered, a certain degree of fertility will be restored. It is considered that balance of gene combinations in the present $\mathrm{BC}_{1}$ plants improved to some extent with the progress of generation.

Chromosome pairings at metaphase-I in the PMCs and seed fertility of 'KS-K-I' 
and 'KS-K-4' pollinated by 'Kyoto No.3' were different in spite of their same chromosome number $(2 \mathrm{n}=24)$. Tokumasu and Kato (1988) suggested that the effect of meiotic difference in plants with the same chromosome number is not large enough to dominate the effect of their genetic differences on the seed fertility. Although it is difficult to ascertain their genetic difference from the present results, the origin of the chromosomes in 'KS-K-I' and 'KS-K-4' may be different. Iwasa and Ellerstrom (1981) reported that there was no correlation between various meiosis disturbances and pollen fertility in Raphanobrassica. In our study on chromosome associations, 'KS-K4' showed almost the same frequency of lagging chromosomes as 'KS-K-I', but the pollen stainability and seed fertility were lower in 'KS-K-4' than in 'KS-K-I'. Our results also indicate that a negative correlation exists between the degree of meiosis disturbances and pollen and seed fertility.

Haga (1938), Fukushima (1945) and Mizushima (1952) indicated that "r" genome in Raphanus is partially homologous to "a"," b"and "c" genomes in Brassica, and Haga (1938) pointed out that in Brassica "a", "b" and "c" genomes are partially homologous. There are one to two autosyndetic pairs in "a" genome (Fukushima, 1945; Mizushima, 1972) and two autosyndetic pairs in "c" genome (Thompson, 1956; Armstrong and Keller, 1982). Tokumasu (1970) reported that some homologous parts exist between heterologous chromosomes in Raphanus. In the present study, one to three trivalents appeared in the PMCs of 'KS-K-I' which may have "a" genome and a part of "c" and "r" genomes. The facts that two possible autosyndetic pairs are known in "a" and "c" genomes, that "r" genome is partially homologous to "a" and "c" genomes, and that " a" and "c" genomes are partially homologous may lead to the conclusion that autosyndesis and allosyndesis occurred simultaneously and formed a trivalent in the PMCs, although it is not obvious whether autosyndesis occurred within "r", "a" or "c" genome.

\section{Clubroot resistance in $\mathrm{BC}_{2}$ progenies}

The results that clubroot resistant BC, plants ('KS-K-I' $\mathbf{x}$ 'Kyoto No.3') with 23 chromosome number were obtained from the segregation of $\mathrm{BC}_{2}$ progenies indicate that allosyndesis may occur among "r", "a" and "c" genomes and that chromosome number decreased as the backcrossing generation advanced. Our results suggest the possibility of transferring the clubroot resistance from Brassicoraphanus to B. campestris and to R. sativus and that of obtaining strong resistant Chinese cabbage and Japanese radish reversional plants through selections from the resistant $\mathrm{BC}$, plants and further backcrossings of the BC, plants with Chinese cabbage and Japanese radish, respectively. However, seed fertility and quality of the reversional resistant plants should be estimated for breeding resistant strains or cultivars of Chinese cabbage or Japanese radish during the backcrossing and selection process.

\section{REFERENCES}

Armstrong, K. C. and W. A. Keller 1982 Chromosome pairing in haploids of Brassicaoleracea. Can. J. G enet. Cytol., 24: 735-739

Dyer, A. F. 1963 The use of lacto-propionic orcein in rapid squash methods for chromosome preparations. Stain Technol., 38: 85-90 
Fukushima, E. 1945 Cytogenetic studies on Brassica and Raphanus. I. Studies on the intergeneric $F_{1}$ hybrids between Brassica and Raphanus. Jour. Dept. Agri.Kyushu Imp. U niv., 7: 281-400

Haga, T. 1938 On chromosomes in the genus Brassica (a collective review). Japan. J. G enet., 14: 7490

Honma, S, and 0. Heeckt 1962 Investigations on $F_{1}$ and $F_{2}$ hybrids between Brassica oleracea var. acephala and Raphanus sativus. Euphytica, 11: 177-180

Iwasa, S. 1964 Cytogenetic studies on the artificially raised trigenomic hexaploid hybrid forms in the genus Brassica. J.Fac. Agr., Kyushu Univ., 13: 209-349

Iwasa, S. and S. Ellerstrom 1981 Meiosis disturbances, aneuploidy and seed fertility in Raphanobrassica. Hereditas, 95: 1-9

Long, M. H., G. M. Xing, H. Okubo and K. Fujieda 1992 Cross compatibility between Brassicora. phanus and cruciferous crops, and rescuing the hybrid embryos through ovary and embryo cultures. J. Fac. Agr., Kyushu U niv., 37: 29-39

McCollum, G. D. 1979 Sterility in successive backcrosses of Raphanobrassica $(2 n=4 x=36)$ with recurrent Brassica oleracea $(2 \mathrm{n}=2 \mathrm{x}=18)$. Can. J. G enet. Cytol., 21: 479-485

McNaughton, I. H. 1973 Synthesis and sterility of Raphanobrassica. Euphytica, 22: 70-88

Mizushima, U. 1952 Karyo-genetical Studies on Brassiceae. Gihodo, Tokyo.

Thompson, K. F. 1956 Production of haploid plants of marrow-stem kale. Nature, 178: 748

Tokumasu, S. 1970 Intergeneric hybrids between Brassica japonica and Raphanus sativus. Mem. Coll. Agr. Ehime Univ., 14: 285-302

Tokumasu, S. and M. Kato 1988 Chromosomal and genic structure of Brassicoraphanus related to seed fertility and the presentation of an instance of improvement of its fertility. Euphytica, 39: 145151

Xing, G. M., M. H. Long, S. Tanaka and K. Fujieda 1989 Clubroot resistance in Brassicoraphanus. J. Fac. Agr., Kyushu Univ., 33: 189-194 